\title{
Discretionary Requirement of Bond For Stay of Execution in California
}

LL LAWYERS in California are familiar with the conditions under
which the mere perfecting of an appeal will not stay execution of a judgment. Thus, an appeal from a money judgment will not stay execution without the filing of a supersedeas bond; ${ }^{1}$ nor an appeal from a judgment directing the sale of personal property upon foreclosure of a mortgage; ${ }^{2}$ nor an appeal from a judgment directing the sale or delivery of possession of real property. ${ }^{3} \mathrm{~A}$ bond is required if the judgment direct the assignment or delivery of documents or personal property, unless the things be placed in the custody of an officer or receiver appointed by the court. ${ }^{4}$ If the judgment or order direct the execution of a conveyance or other instrument, a stay is not effected unless the instrument be executed and deposited with the clerk througliout appeal.5 And finally, a writ of supersedeas is necessary where the order adjudges the defendant guilty of usurping public office, grants or refuses to grant a change of the place of trial, orders a corporation to accord a director, stockholder or member reasonable opportunity to inspect its books, or directs the closing of a building or place adjudged to be a nuisance. ${ }^{6}$

In all other cases it was assumed, prior to 1927, that the perfecting of an appeal, without more, would effect a stay of execution. For after setting forth with precision (in sections 942 to 945 ) the cases in which the mere filing of notice of appeal would not stay execution, the Code of Civil Procedure (section 949) provided:

"In cases not provided for in sections $942,943,944$ and 945 , the perfecting of an appeal stays proceedings in the court below upon the judgment or order appealed from;"

But by an act approved May 16, 1927, ${ }^{\top}$ section 949 was amended inter alia by the addition of the following clause immediately after the excerpt from the section quoted above, viz.:

"but the court in its discretion may require an undertaking in an amount to be fixed by it conditioned for the performance of the judgment or order appealed from if the same is affirmed or the appeal is dismissed;"

Was it the intention of the legislature in enacting the amendment to give to the trial court in all cases other than those provided for in

1 Cad. Code Civ. Proc. $\$ 942$.

2 CaL. Code Civ. Proc. $\$ 943$.

3 CaL. Code Civ. Proc. $\$ 945$.

4 Cal. Code Civ. Proc. \$ 943.

5 Cal. Code Civ. Proc. \$ 944.

6 Car. Code Civ. Proc. \$ 949.

7 Cal. Stats. 1927, p. 874. 
sections 942 to 945 discretion to require the filing of a supersedeas bond? At first glance the breadth of the language employed would seem to lead to this conclusion. Yet if the court in its discretion may require the filimg of an undertaking on appeal in all cases except those provided for in sections 942 to 945 , then it is clear that an altogether extraordinary change in the law has been effected.

It is evident that if any limitation on the power of the court is contained in the statute, it must arise from the provision describing the bond as "conditioned for the performance of the judgment or order appealed from." And, thus, it would seem of some importance to determine whether the expression "performance of the judgment or order appealed from" has any accepted significance in connection with a statutory stay of proceedings.

An enquiry into the matter has disclosed that the expression "performance of the judgment" has been the subject of repeated judicial construction in connection with a stay of proceedings on appeal. As it is believed that the cases may serve to impose a serious limitation on the discretionary power of the court, a brief analysis thereof will be attempted:

The case of In re Schedel ${ }^{8}$ was the first to group the appellants referred to in sections 942 to 945 of the Code of Civil Procedure, and classify them on a common ground. In that case an appeal liad been taken by a legatee from a decree effecting distribution of an estate. $\mathrm{He}$ made an application to the supreme court for a writ of supersedeas to stay proceedings throughout the appeal. The notice of appeal was accompanied by an undertaking in the sum of $\$ 300.00$ then (but not now) required by section 941 of the Code of Civil Procedure. ${ }^{9}$ The question was whether the notice and undertaking stayed proceedings in the court below.

In considering the matter the court for the first time stated the conclusion, simce repeatedly approved, that

"Sections 942 to 945 , inclusive, apply to appellants who are required to perform the directions of the judgment or order appealed from." 10

After observing that under the provisions of the decree the appellant was

8 (1886) 69 Cal. 241, 10 Pac. 334.

9 As originally enacted on March 11, 1872, section 941 read:

"The undertaking on appeal must be in writing, and inust be executed on the part of the appellant, by at least two sureties, to the effect that the appellant will pay all damages and costs which may be awarded against him on the appeal, or on a dismissal thereof, not exceeding three hundred dollars; or that sum must be deposited with the clerk with whom the judgment or order was entered, to abide the event of the appeal." On May 20, 1921, the section was amended to delete the requirement of any bond.

${ }^{10} \mathrm{In}$ re Schedel, supra note 8, at 243, 10 Pac. at 335. Italics here, and elsewhere throughout this article, unless otherwise stated, are the writer's. 
not required to do anything, the court concluded that a stay of proceedings was effected.

The case was soon followed by Born v. Horstmann. ${ }^{11}$ There an appeal was taken from an interlocutory decree entered in an action for partition. The question presented was whether the perfecting of the appeal, together with the filing of the $\$ 300.00$ undertaking prevented the payment of any part of the corpus of the estate or proceeds of the sale of the property in accordance with the terms of the decree. The court noted, first, that "the appellants are not required by the judgment to do anything." 12 Quoting the opinion in In re Schedel ${ }^{13}$ that sections 942 to 945 , inclusive, of the Code of Civil Procedure, apply to appellants who are required to perform the directions of the judgment, the court held that the perfecting of the appeal operated ipso facto as a supersedeas.

The question was presented in Pennie v. Superior Court ${ }^{14}$ in an original proceeding instituted in the supreme court. The appellant sought by certiorari to annul an order of the superior court requiring the petitioner to pay a substantial sum of money to Florence Blythe. The latter had brought an action under section 1664 of the Code of Civil Procedure to have herself decreed to be the heir of the deceased, Thomas Blythe, and a decree had 'been entered in the proceeding in accordance with her prayer. From the decree various claimants (known as the Williams claimants) perfected an appeal. The superior court made an order granting to Florence Blythe a fainily allowance, and from such order the Williams claimants also appealed, giving the required statutory undertaking of $\$ 300.00$. Notwithstanding the filing of the undertaking, the superior court made an order directing the administrator to pay to Florence Blythe the amount of the family allowance. The question was then presented directly: Did the taking of an appeal by the Williams claimants from the order granting a family allowance stay the execution thereof?

The court held that nnder the judgment the appellants were "not required to do anything," and that therefore the perfecting of the appeal, together with the filing of the $\$ 300.00$ undertaking mentioned in section 941 , operated as a supersedeas. Execution of the first order having thus been stayed, the subsequent order directing the payment of the allowance was deemed beyond the jurisdiction of the court. The court noted the essential similarity of the judgment in the Schedel case:

"But as to the main fact upon which the Schedel case was decided, it is identical with the case at bar; namely, that in neither case was the appel-

11 (1889) 80 Cal. 452, 22 Pac. 169.

12 Ibid. at 453, 22 Pac. 169.

13 Supra note 8.

14 (1891) 89 Cal. 31, 26 Pac. 617. 
lant required to 'perform the directions of the judgment or order appealed from." "15

Elsewhere in the opinion, however, the description in the Schedel case of the class of cases to which sections 942 to 945 of the Code of Civil Procedure apply may have been somewhat broadened. Thus, the court observed:

"The general rule, as declared in section 949 , is, that the three-hundred-dollar undertaking mentioned in section 941 'stays proceedings in the court below upon the judgment or order appealed from.' The exceptions are contained in Sections 942 to 945 , mclusive; and those sections apply to cases where the appellant has money or other property in his possession which has been adjudged by the lower court to belong to the respondent, or where the appellant has been directed to do some act for the benefit of respondent, and where it would be unjust to allow the appellant to retain the possession of the property, and perhaps dissipate it or put it out of his power to perforn the act required, without securing respondent by a bond." 16

Whether the attempt to define generally the applicability of sections 942 to 945 in substance extends the definition in In re Schedel, may be doubted, for certainly in the ordinary case where the appellant was in possession of money or property found in the judgment to belong to the respondent, the judgment would direct its payment or delivery. But we are concerned here not ouly with the compass of sections 942 to 945 , but with the manner in which such compass has been defined. For that reason any change or variation of the definition in the Schedel case would seein pertinent.

In the case of In re Woods ${ }^{17}$ there was a contest in the court below for letters of administration of an estate. The public administrator prevailed, and one of the contestants, C. M. West, appealed. At the time of appeal West posted the $\$ 300.00$ undertaking, bnt the public administrator nevertheless proceeded to administer the estate. Accordingly, the appellant applied in the supreme court for an order staying proceedings. The court noted that appellant was "not within the said sections from 942 to 945 , which 'apply to appellants who are required to perform the directions of the judgment or order appealed from,' (Estate of Schedel, 69 Cal. 241.)" 18 and granted appellant's application.

In McCallion, et al., Respondents, v. Hibernia Savings and Loan Society, et al., Appellants, ${ }^{19}$ conflicting claims were made to a fund of several thousand dollars deposited with the Loan Society. The plaintiffs and defendants were various claimants of the fund. In the court below the judgment was rendered "that plaintiffs were entitled to the money; that the city and county treasurer pay the same over to then, and that

\footnotetext{
15 Ibid. at 33, 26 Pac. at $61 \%$.

16 Ibid. at $33,34,26$ Pac. at 617.

17 (1892) 94 Cal. 566, 29 Pac. 1108.

18 Ibid. at 567, $29 \mathrm{Pac}$. at 1108.

19 (1893) 98 Cal. 442, 33 Pac. 329.
} 
the defendants pay the costs of the action, amounting to three hundred and twelve dollars." 20 The defendants appealed and gave a stay bond in double the amount of the judgment and costs. Upon appeal the judgment was affirmed, and upon the return of the remittitur to the trial court, the plaintiffs moved for judgment against the sureties on the bond, all as provided in section 942 of the Code of Civil Procedure. Judgment was rendered against the sureties, and from that judgment an appeal was perfected.

The court poimted out that the record did not disclose a judgment which would require a bond to stay execution, and denied recovery on the bond. As the statute effected a stay without the necessity of a bond, the undertaking on appeal was deemed without consideration and void.

But on behalf of the plaintiffs it was urged that the case was within section 942 of the Code of Civil Procedure. This contention the court demed upon the ground that under the well-established construction of section 942 it "applied only to appellants who were required to perform the directions of the judgment or order appealed from." 21

The plaintiff in the case of Zappettini $v$. Buckles ${ }^{22}$ sought dissolution of a partnership, and judgment was given decreeing "that the partnership was dissolved, declaring that property belonged to the partnership, *** , adjudging that all of said property be sold *** by a receiver theretofore appointed by the court, and that said received after deducting the costs and expenses of sale, pay the remainder of the proceeds into court 'to abide the further order of the court';" and adjudging that the proceeds of the sale be paid and applied in the manner specifically set forth. On appeal no bond other than the $\$ 300.00$ undertaking was filed. An application for a writ of supersedeas was filed and granted in the supreme court. In disposing of the respondent's suggestion that the case came within the provisions of section 945 of the Code of Civil Procedure, the court relied upon Pennie v. Superior Court ${ }^{23}$ to support its conclusion,

"that those sections ( 942 to 945 inclusive) 'apply to cases where the appellant has money or other property in his possession which has been adjudged by the lower court to belong to the respondent, or where the appellant has been directed to do some act for the benefit of the respondent, and where it would be unjust to allow the appellant to retain the possession of the property, and perhaps dissipate it, or put it out of his power to perform the act required, without securing respondent by a bond." 24

In Halsted v. First Savings Bank, ${ }^{25}$ the plaintiff was the special administrator of the estate of the deceased Halsted. In his complaint

20 Ibid at 443, 33 Pac. at 329.

21 Ibid at 444, 33 Pac. at 329.

22 (1914) 167 Cal. 27, 28, 138 Pac. 696, 697.

23 Supra note 14.

24 Zappettini v. Buckles, supra note 22, at 30, 138 Pac. at 697.

25 (1916) 173 Cal. 605, 160 Pac. 1075. 
he asserted that the defendant Bank had to the credit of the deceased a large amount of money at the time of his death. He alleged further that this money stood in the name of the defendant, Anna Collins, who he charged had wrongfully caused the deposit to be changed from the joint name of the deceased and herself to her own individual name. He alleged further that Anna Collins proposed to withdraw the deposit and appropriate the same to her own use. Accordingly he prayed for judgment against the Bank in the amount of the deposit; that Anna Collins be adjudged to have no interest therein; that an order be made restraming the defendant Collins from withdrawing the deposit, and that the Bank be likewise restramed froin paying over the deposit at the direction of Anna Collins. Upon the trial the court held in favor of the defendant Collims. The plaintiffs perfected an appeal from the judgment, giving the ordinary $\$ 300.00$ appeal bond. While the judgment directed that the defendant Collins "do have and recover of and from the defendant, First Savings Bank, the sum of $\$ 11,379.38$ with interest" 26 the Bank did not appeal.

In these circumstances Anna Collins proceeded to enforce her judgment for the recovery of the money from the Bank, and took out a writ of execution to that end. Appellants thereupon applied for a writ of supersedeas to restrain the enforcement of the judgment, upon the ground that the appeal ipso facto effected a stay.

In determining the matter the court noted that in so far as the judgment was one against the appellants, it was stayed by the mere perfecting of the appeal, stating the general rule:

"It must now be taken as absolutely settled by our decisions that the provisions of sections $942,943,944$ and 945 apply only where the appellant has money or other property in his possession or under his control which has been adjudged by the lower court to belong to the respondent, or where the appellant has been directed to do some act for the benefit of the respondent." 27

But the question arose further as to whether the defendant Collins' judginent against the Bank was stayed. Conceivably the court could have said that any judgment in favor of Anna Collins was a judgment against the plaintiff, and thus subject to the effect of the supersedeas. But the court declined so to rule, and held on the contrary that the adjudication in favor of Collins had the effect of a simple money judgment against the Bank, and was not stayable under the statute except upon appeal by the Bank and the filing of the undertaking in twice the amount of

26 Ibid. at 607,160 Pac. at 1076.

27 Ibid. at $608,160 \mathrm{Pac}$. at 1076. 
the judgment provided for in section 942 of the Code of Civil Procedure. 28

Notwithstanding the decision that a stay was not effected under the statute, however, the court granted a writ of supersedeas, under its inherent power to do so, with the provision that the appellant serve the respondent Collins with a proper bond. In this respect, the court's ruling appeared to be based upon the allegations in the application for the writ that once paid to Anna Collins, the amount of the judgment was not recoverable in the event the judgment were reversed. ${ }^{20}$

From the foregoing cases it is apparent that the expression "performance of the judginent" has a well-recognized and accepted signifcance in connection with a statutory stay of execution. The implication results that when the legislature enacted the amendment to section 949, it had the benefit of an established judicial construction of sections 942 to 945 on the one hand, and section 949 on the other. Thus sections 942 to 945 had been construed to relate to particular kinds of judgments directing the performance of some act by the appellant for the benefit of the respondent, and section 949 to cover all other judgments from which appeals could be taken. It is entirely possible, therefore, that the legislature used the expression "performance of the judgment" advisedly in drafting the text of the amendment.

If the discretion of the court in requiring an undertaking under section 949 is thus limited by the condition that the judgment direct the performance by appellant of some act or acts, it is evident that a considerable limitation on the power of the court is established. Instead of authorizing the court to require in its discretion a supersedeas bond in all cases not otherwise provided for by statute, the section would permit the court to exercise its discretion only in the limited number of cases in which the judgment directed the performance of acts not mentioned

28 As appears from the foregoing recitation of facts, judgment against the nonappealing party in the Halsted case was rendered against such party by its codefendant. Whether $\mathrm{m}$ the event that the nonappealing party were a defendant against whom judgment had been entered jointly with the appellant, the ruling would have been the same may be doubted. Thus where one of several appellants effects a stay by the filing of a supersedeas bond, the effect thereof is ordinarily limited to the party filing the bond. But the judgrnent may be of sucb a character that the enforcement thereof against a co-defendant may affect injuriously the rights of the party filing the bond. For example, if a joint judgment is entered against an appellant and a nonappealing defendant, the filing by the appellant of a supersedeas bond will ordinarily stay execution of the judgment against all parties. Eastern Outfitting Company v. Superior Court (1918) 38 Cal. App. 374, 176 Pac. 366.

${ }^{29}$ While it is conceivable that the judgrnent may direct performance of the terms thereof by some person not a party to the action, it is assumed that a superseaces could not be extended to restrain the actions of such party in any way or manner whatsoever. Madera County v. Raymond Granite Counpany (1902) 138 Cal. 244, 71 Pac. 112. 
in sections 942 to 945 of the Code. Some light may be thrown upon the question in the application of both constructions to judgments for which no specific statutory provision lias been made.

We may take, for example, the judgment in the familiar action to foreclose a pledge. In such a case the judgment would in the ordinary course provide for a judgment in favor of the plaintiff and against the defendant in a designated amount, and for a foreclosure and sale of the pledged property to satisfy the judgment. Neither section 942,943 , 944,945 nor 949 makes specific provision for a stay of execution upon appeal froin such a judgment. But the judgment lias been judicially construed as one not directing the performance of any act on the part of the appellant for the benefit of the respondent. Thus in Rohrbacher v. Superior Court, , $^{30}$ the action was "founded upon a promissory note made and executed by the defendant $* * *$ and as collateral security for the payment of said note, the maker thereof, $* * *$ transferred and deposited $* * *$ by way of pledge, a certificate of the capital stock of the Sunnyside Land Company, and also a certain order $* * *$ for family allowance, of three liundred dollars per month $* * *$ " The judgment entered in the case provided "that the plaintiff in said action have judgment against the defendant, petitioner herein, for the sun of $\$ 4,199.16$ 'and a decree of this court foreclosing the pledged property described in the complaint, and for a sale of said property to satisfy the liens thereon,' and by the decree R. H. Fitzgerald was appointed commissioner for the purpose of inaking the said sale." 31 It was contended on behalf of the respondents (who interposed a general demurrer to a petition for supersedeas) that the facts stated in the petition brought the case within the provisions of section 943 of the Code of Civil Procedure, and that therefore a supersedeas bond was required. The court noted, however, that the petitioner (the defendant below) had made

"a delivery of the certificate of stock and an assignment of the order,-
which was all that could be done on the part of the defendant in said action
to transfer and assign the said property as security for said indebtedness." 32

It then cited and relied upon the decision in Pennie v. Superior Court 33 lolding that a bond was required under the provisions of 942 to 945 only where the appellant had money or other property in lis possession belonging to the respondent, or where the appellant has been directed to do some act for the benefit of the respondent. Accordingly the application for supersedeas was granted.

\footnotetext{
30 (1904) 144 Cal. 631, 632, 78 Pac. 22.

31 Ibid at 632, 78 Pac. at 22 .

32 Ibid. at 632, 633, 78 Pac. at 23.

33 Supra note 14.
} 
Upon the basis of this decision, ${ }^{34}$ it might be urged with considerable force that a judgment foreclosing a pledge could not be stayed by a bond conditioned for the "performance of the judgment," and thus that the mere perfecting of an appeal would effect a stay. And this conclusion does not appear illogical when compared with the correlative case presented by the foreclosure of a chattel mortgage.

Thus upon appeal from a judgment foreclosing a chattel mortgage (unlike a judgment foreclosing a pledge), statutory provision is made for the filimg of an undertaking on appeal

"to the effect that the appellant will, on demand, deliver the mortgaged
property to the proper officer if the judgment be affirmed, or in default of
such debivery that the appellant and sureties will, on demand, pay to the
proper officer the full value of such property at the date of the appeal." 35

But this was not always the case, and prior to the enactment of the amendment to section 943 of the Code of Civil Procedure ${ }^{30}$ requiring the filing of the foregoing undertaking, the court had recognized that the mere perfecting of an appeal (together with the filing of the $\$ 300.00$ undertaking then required) effected a stay. ${ }^{37}$

It seems likely that by the amendment to section 943 in question the legislature imtended to place a mortgagee out of possession in the position of a pledgee in possession of collateral in the event that an appeal were perfected from a judgment of foreclosure. Apparently to insure that section 943 would not be construed to place the mortgagee im a better position than the pledgee, the terms of the bond were incorporated in the amendment. The mortgagee was assured thereby of the delivery of the property or of its value as of the date of the appeal: he was not assured necessarily of the payment of his judgment. It seems clear that the security thus afforded the successful mortgagor is precisely that afforded the ordinary pledgee without benefit of an undertaking.

Now an apparent legislative intention to place by statute both lienors in precisely the same position in the event of an appeal from a judgment of foreclosure may militate against any but a limited construction of

34 The case of Rohrhacher v. Superior Court, supra note 30 , has adequate authority to support it. In Owen v. Pomona Land Etc. Co. (1899) 124 Cal. 331, $57 \mathrm{Pac}$. 71, the plaintiffs contended that the judgment foreclosing the lien of a pledge was a dual judgment and insisted that execution was not stayed without the filing of a supersedeas bond. This contention the court denied and permitted a stay upon the filing of the $\$ 300.00$ undertaking. In Commercial etc. Bank of S. J. v. Hornberger (1901) 134 Cal. 90, 66 Pac. 74, Mr. Justice Henshaw considered the question settled by the Owen case. As in the previous cases, the matter was presented upon an application for a writ of supersedeas to prevent the threatened sale of pledged property. In denying the apphication the learned justice observed that any "insecurity of the pledged property is inherent in its very nature."

35 Cal. Code Civ. Proc. $\$ 943$.

36 Cal. Stats. 1897 , p. 56.

37 Snow v. Holmes (1883) 64 Cal. 232, 30 Pac, 806. 
the discretionary power vested in the court by section 949 . For not without difficulty could it be assumed that the legislature intended advisedly to place the pledgee in the better position through the requirement (even at the court's discretion) of the filing of an undertaking on appeal. Indeed, if any intention were imputed to the legislature to vary the respective positions of a pledgee and mortgagee, on appeal, it would be more logical to suppose that the mortgagee out of possession of the property, and not the pledgee in possession, would have been afforded a deficiency bond.

Of course, a comparison of the effect of the 1927 amendment to section 949 on the relative rights of pledgeholders and mortgagees is primarily of value in a case presenting such rights for determination. It affords ouly inferentially a basis upon which to urge that section 949, as amended, vests discretion in the trial court only where the judgment directs the performance of some act on the part of the appellant. It is true that sections 942 to 949 are in pari materia, although enacted and amended at different times, and every effort will be made by the courts to construe the enactments harmoniously. And in view of the legislative history of the sections, it may be doubted that successful application could be made for a supersedeas bond pending appeal from a judgment foreclosing a pledge. But whether reconciliation of the statutes im so far as they apply to pledgees and mortgagees necessarily imvolves the construction that the discretionary power of the court is limited is a question upon which we may come to no more than a tentative conclusion.

This is not the place to stress the difficulties necessarily incident to a judicial determination of "legislative intent." Where statutes of this character are enacted over a period of years whether anything but apparent intent or purpose can be determined is dubious. ${ }^{38}$ In any event, we may be certain that when and as the proper construction of these sections is judicially determmed, the conclusion of the court will be based upon some expression of what was the legislative intent. It may be, therefore, that all that can be attempted at this time is a prophecy of what such expression will be. ${ }^{39}$

38 "A result intelligently foreseen and offering the most obvious motive for an act that will bring it about, fairly may be taken to have been a purpose of the act." Per Mr. Justice Holnes in Miller v. Milwaukee (1927) 272 U. S. 713, 715.

39 Since their enactment in 1927 the provisions of section 949 vesting discretionary powers in the trial court do not appear to have been the subject of judicial construction. In Hayward v. Superior Court (1933) 130 Cal. App. 607, 20 P. (2d) 348 , a motion was made by respondents in the trial court for an order requiring the filing of a discretionary bond. This motion was denied, and the appellate court, upon an ex parte apphication, ordered an alternative writ of unandate upon the theory urged by the respondent that the trial court "dismissed," and distinguished from "denied," its application, and declined to exercise jurisdiction with respect thereto. On further proceedings the writ was denied, Works, P. J., pointing out in his opinion 
It is conceivable that by the 1927 amendment to section 949 the legislature will be deemed to have reaffirmed the established distinction between judgments wherem performance by the appellant is expressly directed and judgments in which no such direction is given, and thereby limited to cases involving the former judgments the power of the court to require the filing of a supersedeas bond. The utilization of the expression "performance of the judgment or order appealed from" as descriptive of the condition of the bond is, no doubt, significant. It will be considered particularly persuasive in the light of the long line of decided cases in which the expression has been construed. It may be thought that the judicial attempt since the enactment of the code to establish a dichotomy of cases in which the judginent, on the one hand, directs performance on the part of the appellant, and, on the other, contains no such direction, precluding, in the one case, and permitting, in the other, a stay by the mere filing of notice of appeal, will prevent the assumption that the phraseology of the amendment was arrived at inartificially.

Of course, it is possible that the expression "performance of the judgment or order appealed from" may have been utilized as the broadest possible expression to cover a multitude of judgments. And in this respect the difficulty of attempting to describe generally the terms of a bond designed to secure respondents in all classes of judgments other than those mentioned in sections 942 to 945 may easily be appreciated. Indeed, the difficulty suggested is great enough to induce the conclusion that no such attempt inay have been made. In any event, as the section is drawn, the difficulty of drafting a bond with the statutory condition, where the judgment contains no direction to appellant for its performance, is obvious. On the whole, it would seem that if the legislature had intended to vest in the lower court unlimited discretion to require a supersedeas bond in all cases other than those for which specific statutory provision was made, it could have done so more happily by leaving the condition, as well as the amount, to the sound discretion of the trial court. ${ }^{40}$

that jurisdiction of the motion was exercised by the trial court when it took and considered that under such circumstances a writ of mandate would not lie. The learned judge did not discuss the extent or compass of the trial court's discretion in the premises. That the existence of possible limitations to such discretion may have been in his mind, however, is suggested by the following excerpt from the opinion:

"Section 949 of the Code of Civil Procedure confers upon the superior court the right to exercise a discretion in determining, in cases to which the section applies, whether a stay bond on appeal shall be required." Ibid. at $608,20 \mathrm{P}$. (2d) at 349 .

40 It may be urged in this connection that the language employed in the amendment to section 949 to describe the condition of the supersedeas bond does not conform precisely to that employed in In re Schedel, supra note 8, to classify the judgments covered by sections 942 to 945 of the Code. And in this fashion it may be 
While it is true that the construction of the section suggested by an examination of the foregoing cases confines narrowly the cases in which the respondent may make application for an order requiring the filing of a supersedeas bond, ${ }^{41}$ by no means does it deprive the statute of all legal significance. For in so far as particular judgments directing performance by appellant of their terms are not expressly covered by sections 942 to 945 , they are covered by the amendment to section 949 . It may be assumed that in all appeals from such judgments a stay without bond is no longer a matter of right but of discretionary action on the part of the trial court.

It is to be expected that the courts will continue to find some difficulty in determining what judgments by their terms direct the performance of the judgment. But specific classes of judgments will be comparatively free from doubt. Thus, it may be assumed that the filing of notice of appeal will still stay execution where an appeal is perfected by an heir or legatee from a decree effectimg distribution of an estate; ${ }^{42}$ or where the appeal is taken from a judgment entered in an action for partition; ${ }^{42 a}$ or in a proceeding to determine heirship. ${ }^{43}$ We may conclude, likewise, that the appeal will stay execution in an action of interpleader

argued that while the attempted classification of the particular judgments referred to in sections 942 to 945 , inclusive, is accurate enough and perhaps useful in a case where apphication for supersedeas is made under any one of these sections, the significance of the grouping is primarily descriptive of those judgments. The argument ineets some difficulty perhaps in the fact that in Rohrbacher v. Superior Court, supra note 30 , the classification itself appeared to have been utilized to justify a stay where the judgment did not come withm sections 942 to 945 . Thus, in the Rohrbacher case the court might have justified the stay under section 949 upon the ground that a judgment foreclosing a pledge was not covered by the phraseology of sections 942 to 945 , regardless of whether the judgment directed performance by the appellant of its terms.

I1 It may be thought on principle that the court should be permitted, in its sound discretion, to determine in any case the necessity of an undertaking on appeal. The language employed in the section is broad, and presumably, after a full hearing on the merits, the court could arrive at a just and accurate conclusion both as to the necessity and amount of a supersedeas bond. Even in the case of an appellant pledgee in possession of the pledged property the argument could be made. For conceivably depreciation in the trust property might be such that at the date of judgment, foreclosure before or after appeal could not effect repayment of the judgment debt. But on the contrary it might be argued that the matter of supersedeas without bond is altogether too vital a matter to be shorn of precise statutory regulation. It is evident that the determination of whether a judgment would be stayed with or without bond could, as a practical matter, in many instances effectively dispose of the appeal. Whether there should be reposed in the trial court power to make such determimation, particularly where the judgment does not direct performance by the appellant of any act for the benefit of the respondent, is a question upon which opposite conclusions might be reached.

42 In re Schedel, supra note 8.

42a Born v. Horstmann, supra note 11.

43 Pennie v. Superior Court, supra note 14. 
unless perfected by a party having the fund in his possession; ${ }^{44}$ or in an action to dissolve a partnership; ${ }^{45}$ or in a contest for letters of administration of an estate. ${ }^{46}$ Finally, we may assume that execution will be stayed by appeal froin the ordinary judgment foreclosing a pledge. ${ }^{47}$ As the character of other judgments is presented for determination, it may be that these cases by analogy will point the way.

Barry Brannen.

Los Angetes, Cattpornia.

44 McCallion v. Hibernia Sav. \& Loan Assoc., suspra note 19.

45 Zappettini v. Buckles, supra note 22.

46 In re Woods, supra note 17.

47 Rohrbacher v. Superior Court, sup.ra note 30 . In this regard we have in mind the usual judgment of foreclosure. It is conceivable that in this connection the trial court could incorporate in the judgment conditions which would require the performance of some act on appellant's part, and if such conditions were witbin its jurisdiction, a basis would be laid for an apphication by respondent for a discretionary bond on appeal. 